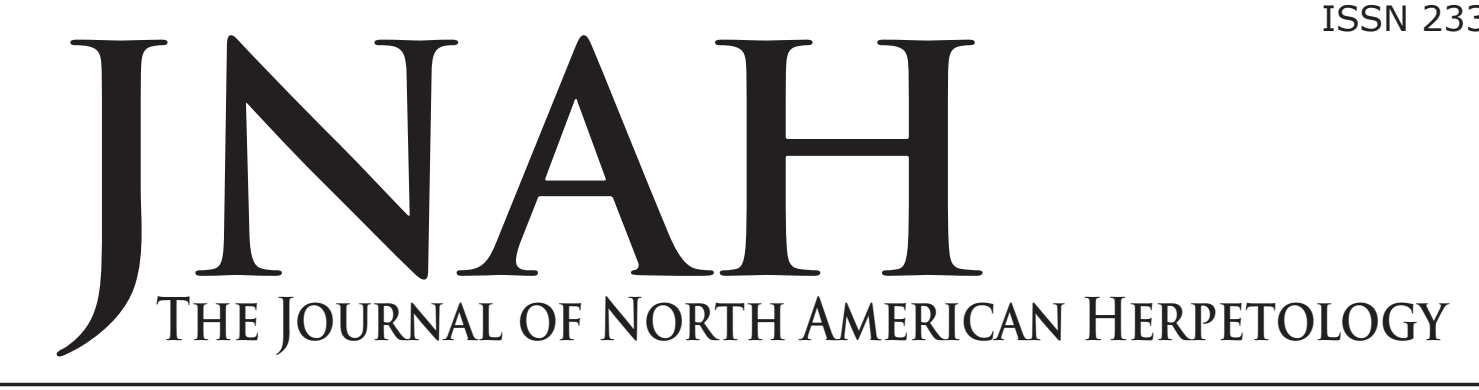

Volume 2014(1): 59-68 31 January 2014 jnah.cnah.org

\title{
AMPHIBIAN AND REPTILE COLONIZATION OF RECLAIMED COAL SPOIL GRASSLANDS
}

\author{
VANESSA C. K. TERRELL ${ }^{1,2}$, JAIMIE L. KLEMISH ${ }^{1}$, NATHAN J. ENGBRECHT ${ }^{3}$, JOHN A. MAY4, \\ PETER J. LANNOO ${ }^{5}$, ROCHELLE M. STILES ${ }^{1}$, AND MICHAEL J. LANNOO ${ }^{3,6}$ \\ ${ }^{1}$ Department of Biology, Indiana State University, Terre Haute, Indiana, USA \\ ${ }^{2}$ Warnell School of Forestry and Natural Resources, University of Georgia, Athens, Georgia, USA \\ ${ }^{3}$ Department of Anatomy and Cell Biology, Indiana University School of Medicine-TH, Terre Haute, \\ Indiana, USA \\ ${ }^{4}$ Department of Computer Science and Software Engineering, Rose-Hulman Institute of Technology, \\ Terre Haute, Indiana, USA \\ ${ }^{5}$ College of Arts and Sciences, Cornell University, Ithaca, New York, USA \\ ${ }^{6}$ Corresponding author. E-mail: mlannoo@iupui.edu
}

\begin{abstract}
While habitat loss is a major driver of amphibian and reptile declines globally, a subset of post-industrial landscapes, reclaimed and restored, are creating habitat for these animals. In a previous work, we showed that amphibians and reptiles use reclaimed and restored grasslands. In the present work we quantify captures at drift-fence/pitfall trap arrays over two consecutive years and show that several species of amphibians are not only successfully reproducing but that juveniles are being recruited into the population. In particular, 15,844 amphibians and 334 reptiles representing 25 species (14 amphibians, 11 reptiles) were captured at drift fences in 2009 and 2010. Nine additional reptile species were found opportunistically while conducting other research activities at the study site. Out of a total of 8,064 metamorphosing juveniles we detected 126 malformations, a $1.6 \%$ rate. The major malformation types were limbs missing (amelia) or foreshortened (ectromely), eye discolorations, and digits foreshortened (ectrodactyly) or small (brachydactyly). Our data show that reclaimed, restored, and properly managed landscapes can support reproducing populations of amphibians and reptiles with low malformation rates, including species in decline across other portions of their range.
\end{abstract}

Key words: Population, Recruitment, Colonization, Reclamation, Coal mining

\section{INTRODUCTION}

Amphibians are facing an extinction crisis. Globally, nearly $25 \%$ of all species are facing extinction, while another $25 \%$ are threatened (Stuart et al., 2004; Collins and Crump, 2009; Wake, 2012). Habitat destruction, disease, invasive species, pollution, and the pet trade are all factors known to negatively influence amphibian populations (Collins and Storfer, 2003; Stuart et al., 2004; Daszak et al., 2005). Habitat loss has been proposed as the most important overall cause of amphibian declines (Collins and Storfer, 2003; Bradford, 2005; Gallant et al., 2007). Although less well publicized, reptiles are facing a comparable crisis for similar reasons (Gibbons et al., 2000; Reading et al., 2010; Sinervo et al., 2010; Chessman, 2011; Böhm et al., 2013).
One cause of habitat loss that has received much recent attention centers on energy extraction (Nikiforuk, 2010; Reece and Krupa, 2013). Energy extraction both destroys habitat for amphibians and reptiles and introduces contaminants that compromise future reclamation and restoration efforts. For example, the surface mining of oil sands in northeastern Alberta, Canada has resulted in clearing large portions of the Boreal Forest and draining wetlands; processing of these oil-permeated sands then results in waste byproducts that either exclude or compromise amphibian populations (Pollet and Bendell-Young, 2000; Hersikorn et al., 2010; Hersikorn and Smits, 2011). In the Midwestern United States, surface mining for coal has altered and in some cases destroyed amphibian habitat. However, following the implementa- 
tion of the Surface Mining Control and Reclamation Act (SMCRA) of 1977, extraction industries are now required to comply with national reclamation standards (Office of Surface Mining Reclamation and Control, 2008). Under SMCRA standards, habitats destroyed as a result of coal mining must be restored to their previous use, a historical use, or to a standard that is equally or more economically productive. In southwestern Indiana, historic surface-mined sites are now being used as agricultural fields, housing developments, and recreational sites. When reclaimed sites are targeted for wildlife habitat, they have historically been planted as grasslands. This is because the soil compaction produced by the heavy earthmoving equipment used to re-contour these sites restricts the ability of tree roots to penetrate the soil (Bajema et al., 2001). This emphasis on grassland construction has expanded the available prairie habitat in the central and southern portions of the Midwest (Lannoo et al., 2009).

The ability of vertebrates to colonize reclaimed mine spoil prairies is well known, and has been reported for birds (DeVault et al., 2002; Scott et al., 2002; Scott and Lima, 2004), small mammals (Hingtgen and Clark, 1984; Stone, 2007), amphibians (Myers and Klimstra, 1963; Timm and Meretsky, 2004; Anderson and Arruda, 2006; Kinney et al., 2010), and reptiles (Myers and Klimstra, 1963). Most studies on amphibian and reptile recolonizations have focused on documenting species presence, diversity, and abundance (Myers and Klimstra, 1963; Galán, 1997; Timm and Meretsky, 2004; Loughman, 2005; Carrozzino, 2009; Lannoo et al., 2009); fewer have reported on population sizes, reproductive potential, and malformation rates (but, see Galán, 1997; Loughman, 2005).

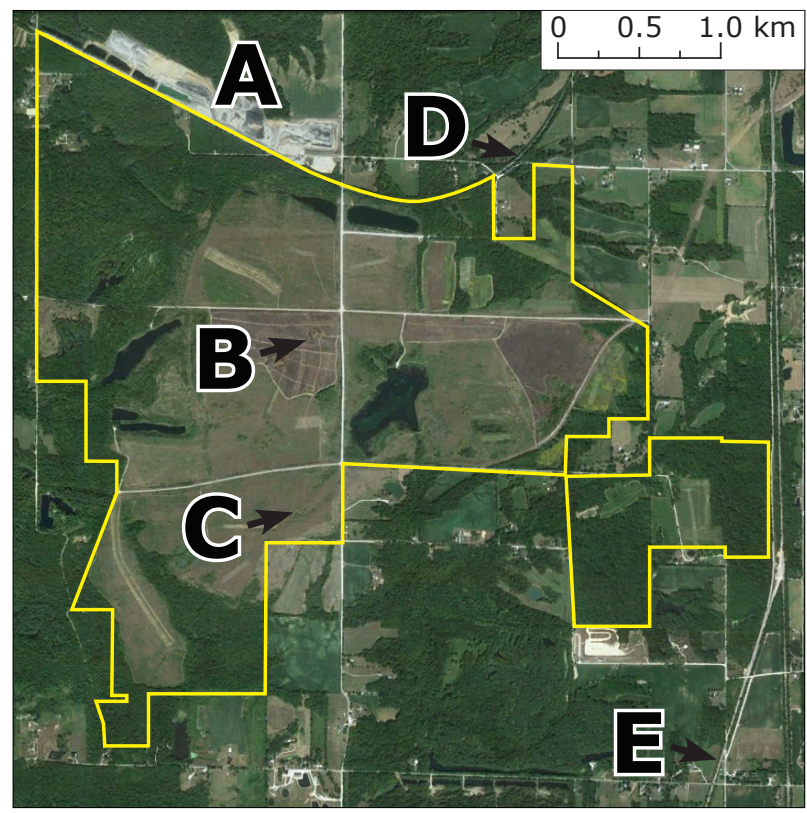

Figure 1. Aerial image of Hillenbrand Fish and Wildlife Area-West (HFWA-W), in Greene County, Indiana. Yellow lines demarcate boundaries of state-owned property. Note that HFWA-W consists of a large central grassland punctuated with lakes and small seasonal and semi-permanent wetlands, surrounded by forested (dark green) and agricultural (light green or brown) areas. We indicate the location of our two study ponds (Cattail [A] and Nate's $[B]$ ). As well, we note railroad tracks ( $D$ and $E$; potential wildlife corridors), and an active coal mine (A) that borders the northwestern edge of the property.
Previously, we documented the diversity and relative abundance of amphibians and reptiles following a oneyear survey at a reclaimed mine spoil prairie in southwest Indiana (Lannoo et al., 2009; Kinney et al., 2010). In the present contribution we expand these initial surveys to a second year and detail population sizes, juvenile recruitment (sensu Hocking et al., 2008), and juvenile malformation rates among the amphibian species present (98.2\% of the individuals observed). Our data show that areas once stripped of their ecology but since reclaimed, restored, and properly managed can be colonized by amphibians and reptiles to produce successfully breeding and presumably sustainable populations with low malformation rates, including populations of species in decline across other portions of their range.

\section{MATERIALS AND METHODS}

Study Site - Our study site was located on the western region of the Hillenbrand Fish and Wildlife Area (HFWA-W) in Greene County, Indiana (Figure 1). HFWA-W comprises 729 hectares that was historically (pre-1850s) eastern deciduous forest punctuated by pocket prairies (Transeau, 1935; Jones and Cushman, 2004), then converted to agricultural fields (beginning in the mid- to late-nineteenth century and extending into the twentieth century) prior to being surface mined for coal in 1976 (Lannoo et al., 2009). Following mining, in 1982, this area was contoured and seeded to herbaceous cover vegetation. In 1988, this property was purchased by the Indiana Department of Natural Resources (IDNR) for use as a state fish and wildlife area, and was gradually re-seeded to prairie species such as Big Bluestem ( $A n-$ dropogon gerardii), Little Bluestem (Schizachyrium scoparium), Indian Grass (Sorghastrum nutans), Partridge Pea (Chamaecrista fasciculata), Black-eyed Susan (Rudbeckia hirta), and Common Milkweed (Asclepias syriaca). HFWA-W is now managed by the IDNR Division of Fish and Wildlife (Lannoo et al., 2009).

As a result of mining activities, post-mining habitat restoration, and erosion control, HFWA-W now contains several bodies of water ranging in hydroperiod from ephemeral wetlands, through semi-permanent wetlands, to large final-cut lakes (Figure 1). As part of a collaborative project to study the biology of Crawfish Frogs (Lithobates areolatus) at HFWA-W, the presence of other amphibian and reptile species was monitored at two of these wetlands, Nate's Pond and Cattail Pond, as well as surrounding uplands (Kinney, 2011).

Nate's Pond is an ephemeral wetland, approximately 0.14 ha in size, that reaches a maximum depth of 0.5 $\mathrm{m}$ in the spring. It was formed unintentionally at the initial site of mining excavation. On the southeastern side of the wetland is a large hill where the first spoils were dumped. The wetland itself lies on re-contoured ground that creates a slight slope facing the hill, causing water to accumulate in the resulting depression. Woody vegetation in the pond includes willows (Salix spp.) and Eastern Cottonwoods (Populus deltoides). Within the wetland, willows and hybrid cattails (Typha angustifolia $x$ latifolia) predominate. The center of the wetland is characterized by a small open-water area with scattered rushes (Scirpus sp.) and aquatic macrophytes. The uplands surrounding the wetland basin consist of restored prairie.

Cattail Pond is a larger, semi-permanent wetland approximately 0.33 ha, with a maximum depth of $1 \mathrm{~m}$. Cattail Pond was also formed unintentionally from either a depression created by uneven contouring during the rec- 
Table 1. A complete listing of the number of individual amphibians and reptiles collected at Hillenbrand Fish and Wildlife Area-West, sorted by species, wetland, and year. Dashed entries represent incidental captures away from these wetlands.

\begin{tabular}{|c|c|c|c|c|c|}
\hline Scientific Name & $\begin{array}{r}\text { Nate's } \\
2009\end{array}$ & $\begin{array}{r}\text { Nate's } \\
2010\end{array}$ & $\begin{array}{r}\text { Cattail } \\
2009\end{array}$ & $\begin{array}{r}\text { Cattail } \\
2010\end{array}$ & Total \\
\hline \multicolumn{6}{|l|}{ Salamanders } \\
\hline Ambystoma opacum & 1,479 & 904 & 75 & 83 & 2,541 \\
\hline Ambystoma texanum & 646 & 561 & 579 & 597 & 2,383 \\
\hline Ambystoma tigrinum & 4 & - & 22 & 12 & 38 \\
\hline Notophthalmus viridescens & 809 & 627 & 297 & 203 & 1,936 \\
\hline Plethodon cinereus & - & 1 & - & - & 1 \\
\hline Total & 2,938 & 2,093 & 973 & 895 & 6,899 \\
\hline \multicolumn{6}{|l|}{ Frogs } \\
\hline Acris blanchardi & 11 & 15 & 18 & 21 & 65 \\
\hline Anaxyrus fowleri & 2 & 4 & - & - & 6 \\
\hline Hyla chrysoscelis & 1 & 11 & - & - & 12 \\
\hline Lithobates areolatus & 367 & 2161 & 42 & 22 & 2,592 \\
\hline Lithobates catesbeianus & 8 & 8 & 25 & 47 & 88 \\
\hline Lithobates clamitans & 149 & 139 & 1980 & 506 & 2,774 \\
\hline Lithobates sphenocephalus & 947 & 604 & 300 & 209 & 2,060 \\
\hline Pseudacris crucifer & 140 & 73 & 13 & 5 & 231 \\
\hline Pseudacris triseriata & 511 & 372 & 112 & 122 & 1,117 \\
\hline Total & 2,136 & 3,387 & 2,490 & 932 & 8,945 \\
\hline \multicolumn{6}{|l|}{ Snakes } \\
\hline Carphophis amoenus & 1 & - & - & - & 1 \\
\hline Clonophis kirtlandii & - & - & - & - & - \\
\hline Coluber constrictor & 1 & - & 2 & - & 3 \\
\hline Diadophis punctatus & 1 & - & - & - & 1 \\
\hline Heterodon platirhinos & - & - & - & - & - \\
\hline Lampropeltis calligaster & - & - & - & - & - \\
\hline Lampropeltis getula & - & - & - & - & - \\
\hline Lampropeltis triangulum & - & - & - & - & - \\
\hline Nerodia sipedon & - & - & 1 & - & 1 \\
\hline Opheodrys aestivus & - & - & - & - & - \\
\hline Storeria dekayi & 1 & 13 & 2 & - & 16 \\
\hline Thamnophis sauritus & 3 & 3 & 5 & - & 11 \\
\hline Thamnophis sirtalis & 1 & 2 & 5 & 4 & 12 \\
\hline Total & 8 & 18 & 15 & 4 & 45 \\
\hline \multicolumn{6}{|l|}{ Turtles } \\
\hline Chelydra serpentina & 5 & 1 & 18 & 4 & 28 \\
\hline Chrysemys picta & 30 & 14 & 117 & 37 & 198 \\
\hline Sternotherus odoratus & - & - & - & - & - \\
\hline Terrapene carolina & 25 & 17 & 4 & 7 & 53 \\
\hline Trachemys scripta & 4 & 2 & 3 & 1 & 10 \\
\hline Total & 64 & 34 & 142 & 49 & 289 \\
\hline \multicolumn{6}{|l|}{ Lizards } \\
\hline Plestiodon fasciatus & - & - & - & - & - \\
\hline Scincella lateralis & - & - & - & - & - \\
\hline Total & 5,146 & 5,532 & 3,620 & 1,880 & 16,178 \\
\hline
\end{tabular}

lamation process or by slumping afterward. Cattail Pond is circular; hybrid cattails predominate, occurring densely everywhere except in the center of the pond where there is a roughly circular opening of deeper water. Upland vegetation consists of restored prairie, similar in species composition to the assemblage surrounding Nate's Pond. Sampling Techniques - We used drift fences paired with pitfall traps to monitor amphibian and reptile movement into and out of wetlands (Gibbons and Bennett, 1974; Gibbons and Semlitsch, 1981; Dodd and Scott, 1994). Full drift fences were installed around Nate's and Cattail ponds in February 2009 after the ground had thawed enough to dig; fencing was placed approximate- ly $5 \mathrm{~m}$ from the wetland edge. Fence material consisted of woven polypropylene composite fence, 1-m high and buried roughly $10-15 \mathrm{~cm}$ below ground, with support stakes placed every $5 \mathrm{~m}$. Hardware cloth was later installed at drainage areas to prevent the washing out of fences during flood events (Lamoureux et al., 2002; Heemeyer et al., 2010). In 2010, we used a more durable monofilament silt fence reinforced by wooden $5 \mathrm{x}$ $60 \mathrm{~cm}$ laths. Pitfall traps consisted of $15-\mathrm{L}$ white square buckets placed every $10 \mathrm{~m}$ along the inside and outside of the fencing (Heemeyer et al., 2010). Each bucket was fitted with a half lid (open side closest to the fence) to provide shade for trapped animals and deter predators 
Table 2. Numbers of amphibians captured at Nate's Pond in a drift fence/pitfall trap array, sorted by year, sex, and life history stage. Note that A. opacum, A. texanum, N. viridescens, L. areolatus, and L. sphenocephalus predominate. Here, subadults are defined as animals intermediate in size between newly metamorphosed juveniles and adults; natal juveniles indicate recently metamorphosed animals dispersing from our study wetlands; immigrating juveniles indicate juveniles from other wetlands entering our study wetlands.

\begin{tabular}{|c|c|c|c|c|c|c|c|}
\hline Species & Female & Male & Subadult & $\begin{array}{r}\text { Natal } \\
\text { Juveniles }\end{array}$ & $\begin{array}{r}\text { Immigrating } \\
\text { Juveniles }\end{array}$ & Unknown & Total \\
\hline Acris blanchardi & 7 & 3 & - & 1 & - & - & 11 \\
\hline Ambystoma opacum & 133 & 254 & 48 & 943 & 101 & - & 1,479 \\
\hline Ambystoma texanum & 131 & 159 & 114 & 199 & 29 & 14 & 646 \\
\hline Ambystoma tigrinum & - & - & - & 1 & 3 & - & 4 \\
\hline Anaxyrus fowleri & - & - & - & - & 2 & - & 2 \\
\hline Hyla chrysoscelis & - & - & - & - & - & 1 & 1 \\
\hline Lithobates areolatus & 31 & 38 & 1 & 286 & 11 & - & 367 \\
\hline Lithobates catesbeianus & - & - & - & - & 8 & - & 8 \\
\hline Lithobates clamitans & 10 & 4 & - & 47 & 88 & - & 149 \\
\hline Lithobates sphenocephalus & 54 & 71 & 14 & 625 & 183 & - & 947 \\
\hline Notophthalmus viridescens & 41 & 43 & - & 667 & 58 & - & 809 \\
\hline Plethodon cinereus & - & - & - & - & - & - & - \\
\hline Pseudacris crucifer & 53 & 51 & - & 35 & 1 & - & 140 \\
\hline Pseudacris triseriata & 279 & 196 & - & 32 & 1 & 3 & 511 \\
\hline \multirow[t]{3}{*}{ Total } & 739 & 819 & 177 & 2,836 & 485 & 18 & 5,074 \\
\hline & & & 2010 & & & & \\
\hline & Female & Male & Subadult & $\begin{array}{r}\text { Natal } \\
\text { Juveniles }\end{array}$ & $\begin{array}{r}\text { Immigrating } \\
\text { Juveniles }\end{array}$ & Unknown & Total \\
\hline Acris blanchardi & 3 & 4 & 5 & - & - & 3 & 15 \\
\hline Ambystoma opacum & 46 & 62 & 5 & 751 & 27 & 13 & 904 \\
\hline Ambystoma texanum & 248 & 251 & 42 & 12 & 3 & 5 & 561 \\
\hline Ambystoma tigrinum & - & - & - & - & - & - & - \\
\hline Anaxyrus fowleri & 3 & - & - & - & 1 & - & 4 \\
\hline Hyla chrysoscelis & - & - & - & 1 & 9 & 1 & 11 \\
\hline Lithobates areolatus & 22 & 20 & 2 & 2,103 & 14 & - & 2,161 \\
\hline Lithobates catesbeianus & 1 & - & 1 & 1 & 5 & - & 8 \\
\hline Lithobates clamitans & 9 & 8 & 1 & 21 & 100 & - & 139 \\
\hline Lithobates sphenocephalus & 13 & 23 & 1 & 243 & 323 & - & 603 \\
\hline Notophthalmus viridescens & 48 & 35 & 15 & 519 & 10 & - & 627 \\
\hline Plethodon cinereus & - & - & - & - & - & 1 & 1 \\
\hline Pseudacris crucifer & 36 & 26 & - & 5 & 6 & - & 73 \\
\hline Pseudacris triseriata & 192 & 172 & 1 & 6 & - & 1 & 372 \\
\hline Total & 621 & 601 & 73 & 3,662 & 498 & 24 & 5,479 \\
\hline
\end{tabular}

(raccoons, skunks, opossums, feral cats). We placed a sponge in each trap to help prevent desiccation of animals during warm weather and provide a floating substrate for animals when buckets flooded, and we placed a $2.5 \mathrm{~cm} \times 2.5 \mathrm{~cm} \times 40 \mathrm{~cm}$ stake in each bucket to facilitate small mammal escape (Dodd and Scott, 1994).

Nate's Pond was enclosed with $270 \mathrm{~m}$ of fencing and 26 pairs of pitfall traps; Cattail Pond was enclosed with $280 \mathrm{~m}$ of fencing and 27 pairs of pitfall traps (later, one of these pitfall traps located in a perennially wet area was removed). In 2009, pitfall traps were opened from 5 March-16 October. In 2010, pitfall traps were opened from 1 March-19 August. Throughout the spring amphibian breeding season, pitfall traps were checked once daily immediately after sunrise; on rainy nights traps were checked multiple times (Heemeyer et al., 2010). In addition to using these trap arrays, we captured amphibians and reptiles opportunistically while walking the trails to the wetlands and while conducting other research activities at our study site.

We identified captured amphibians and reptiles to species and life history stage (juvenile or adult); adults were sexed, juveniles were examined for external mal- formations. Upon first encounter at pitfall traps, all ranids and ambystomatids were given two toe clips, one representing the year, the other representing the pond; newly metamorphosed juveniles and adults were given separate cohort clips to differentiate life-history stages. Adult Crawfish Frogs were implanted with a passive integrated transponder (PIT) tag (Christy, 1996). PIT tags were inserted subcutaneously in unanesthetized animals by using cuticle scissors to make a small incision, just larger than the diameter of the tag, on the ventral flank, behind the forelimb, before inserting a sterile tag. Recaptures show that these wounds heal over by the next day (Lannoo, unpublished data, including photographs). Definitions of malformation types follow Meteyer (2000) and Lannoo (2008).

\section{RESULTS}

Species Diversity and Abundance - We found 34 species of amphibians and reptiles at HFWA-W; 10 species were new county records for Greene County (Lannoo et al., 2009; Kinney et al., 2010). We captured a total of 15,844 amphibians and 334 reptiles representing 25 species (14 amphibians, 11 reptiles) at drift fences 
Table 3. Numbers of amphibians captured at Cattail Pond in a drift fence/pitfall trap array, sorted by year, sex, and life history stage. Note that L. clamitans predominate. Here, subadults are defined as animals intermediate in size between newly metamorphosed juveniles and adults; natal juveniles indicate recently metamorphosed animals dispersing from our study wetlands; immigrating juveniles indicate juveniles from other wetlands entering our study wetlands.

\begin{tabular}{|c|c|c|c|c|c|c|c|}
\hline Species & Female & Male & $\begin{array}{r}2009 \\
\text { Subadult }\end{array}$ & $\begin{array}{r}\text { Natal } \\
\text { Juveniles }\end{array}$ & $\begin{array}{r}\text { Immigrating } \\
\text { Juveniles }\end{array}$ & Unknown & Total \\
\hline Acris blanchardi & 3 & 6 & - & 4 & 4 & 1 & 18 \\
\hline Ambystoma opacum & 22 & 22 & - & 15 & 15 & 1 & 75 \\
\hline Ambystoma texanum & 155 & 243 & 96 & 59 & 21 & 5 & 579 \\
\hline Ambystoma tigrinum & 2 & 10 & - & 1 & 9 & - & 22 \\
\hline Anaxyrus fowleri & - & - & - & - & - & - & - \\
\hline Hyla chrysoscelis & - & - & - & - & - & - & - \\
\hline Lithobates areolatus & 14 & 14 & - & 11 & 3 & - & 42 \\
\hline Lithobates catesbeianus & 6 & 1 & 2 & 4 & 11 & 1 & 25 \\
\hline Lithobates clamitans & 11 & 18 & 17 & 1507 & 424 & 3 & 1980 \\
\hline Lithobates sphenocephalus & 18 & 98 & 4 & 47 & 131 & 2 & 300 \\
\hline Notophthalmus viridescens & 110 & 88 & - & 49 & 45 & 5 & 297 \\
\hline Plethodon cinereus & - & - & - & - & - & - & - \\
\hline Pseudacris crucifer & 8 & 4 & - & 1 & - & - & 13 \\
\hline Pseudacris triseriata & 59 & 41 & - & 10 & 1 & 1 & 112 \\
\hline \multirow[t]{3}{*}{ Total } & 408 & 545 & 119 & 1,708 & 664 & 19 & 3463 \\
\hline & & & 2010 & & & & \\
\hline & Female & Male & Subadult & $\begin{array}{r}\text { Natal } \\
\text { Juveniles }\end{array}$ & $\begin{array}{r}\text { Immigrating } \\
\text { Juveniles }\end{array}$ & Unknown & Total \\
\hline Acris blanchardi & 6 & 7 & 2 & - & 3 & 3 & 21 \\
\hline Ambystoma opacum & 11 & 8 & 3 & 48 & 11 & 2 & 83 \\
\hline Ambystoma texanum & 275 & 272 & 29 & 13 & 6 & 2 & 597 \\
\hline Ambystoma tigrinum & 4 & 2 & - & 2 & 4 & - & 12 \\
\hline Anaxyrus fowleri & - & - & - & - & - & - & - \\
\hline Hyla chrysoscelis & - & - & - & - & - & - & - \\
\hline Lithobates areolatus & 7 & 14 & - & - & 1 & - & 22 \\
\hline Lithobates catesbeianus & 3 & 4 & 16 & 1 & 23 & - & 47 \\
\hline Lithobates clamitans & 34 & 42 & 13 & 34 & 382 & 1 & 506 \\
\hline Lithobates sphenocephalus & 33 & 34 & - & 47 & 95 & - & 209 \\
\hline Notophthalmus viridescens & 51 & 37 & 7 & 86 & 22 & - & 203 \\
\hline Plethodon cinereus & - & - & - & - & - & - & - \\
\hline Pseudacris crucifer & 3 & 2 & - & - & - & - & 5 \\
\hline Pseudacris triseriata & 59 & 49 & 3 & 9 & 1 & 1 & 122 \\
\hline Total & 486 & 471 & 73 & 240 & 548 & 9 & 1,827 \\
\hline
\end{tabular}

across the two years of this study (Table 1 ). We found nine additional reptile species, Clonophis kirtlandii, Heterodon platirhinos, Lampropeltis calligaster, L. getula, L. triangulum, Opheodrys aestivus, Sternotherus odoratus, Plestiodon fasciatus, and Scincella lateralis, opportunistically while conducting other research activities at the study site (Table 1 ). In total, amphibians constituted $98.2 \%$ of our observations.

Amphibian species most often found in pitfall traps were Marbled Salamanders (Ambystoma opacum), Small-mouthed Salamanders ( $A$. texanum), Southern Leopard Frogs (Lithobates sphenocephalus), Crawfish Frogs (L. areolatus), Green Frogs (L. clamitans), and Western Chorus Frogs (Pseudacris triseriata; Table 1). Reptile capture rates were low at drift fences, with several species represented by only one individual. Painted Turtles (Chrysemys picta), Eastern Box Turtles (Terrapene carolina), and Snapping Turtles (Chelydra serpentina) predominated (Table 1 ).

Amphibian Breeding - Amphibian breeding assemblages (sensu Lannoo et al., 1994) were consistent across years within ponds, but varied across the two ponds sampled. At Nate's Pond, predominant species included A. opacum, A. texanum, Eastern Newts (Notophthalmus

viridescens), and $P$. triseriata. The four ranids captured (L. areolatus, L. catesbeianus, L. clamitans, and L. sphenocephalus) were common, but adults were not present in large numbers (Table 2). At Cattail Pond, $A$. texanum and $N$. viridescens predominated (Table 3 ). Numbers of adults varied between years at both ponds, with some species such as $A$. opacum at Nate's Pond fluctuating as much as four fold (Table 2). Recapture data showed that a subset of $A$. opacum, $A$. texanum, $L$. clamitans, and $L$. sphenocephalus juveniles produced in 2009 returned in 2010 as breeding adults (Table 4).

Juvenile Recruitment and Immigration - Numbers of juveniles produced varied by wetland and across years. At Nate's Pond, juvenile $A$. opacum, $A$. texanum, N. viridescens, L. areolatus, and L. sphenocephalus were produced in large numbers (Table 2). At Cattail Pond, only L. clamitans were produced in large numbers (Table 3 ). Under drying conditions in 2010 at Nate's Pond, juvenile Green Frogs metamorphosed in one season. In addition to supporting successful reproduction, each wetland received immigrant juveniles from other sites. The most abundant immigrant species at Nate's Pond were $A$. opacum, L. clamitans, and L. sphenocephalus (Table 2), while at Cattail Pond, L. clamitans and L. sphenocephalus 
Table 4. Recruitment at Nate's and Cattail ponds as represented by metamorphic individuals originally captured exiting ponds in 2009 and recaptured returning to ponds in 2010 .

\begin{tabular}{lr}
\hline \multicolumn{1}{c}{ Nate's Pond } \\
Species & No. of Individuals \\
\hline \hline Ambystoma opacum & $11^{\mathrm{a}}$ \\
Ambystoma texanum & $1^{\mathrm{b}}$ \\
Lithobates sphenocephalus & $5^{\mathrm{c}}$ \\
\hline
\end{tabular}

a3 females, 7 males, 1 juvenile; ${ }^{\circ} 1$ male; ${ }^{5} 5$ males

\begin{tabular}{lr}
\hline Cpecies & No. of Individuals Pond \\
\hline \hline Lithobates clamitans & $1^{\text {a }}$ \\
Lithobates sphenocephalus & $2^{\text {b }}$
\end{tabular}

a 1 male ; ${ }^{b} 1$ female, 1 male

predominated (Table 3).

Malformation Rates and Types - Out of a total of 8,064 metamorphosing juveniles we detected 126 malformations, a $1.6 \%$ malformation rate (Table 5). At Nate's Pond, we found 90 malformations among the 6,388 metamorphosing juveniles, a $1.4 \%$ rate. The major malformation types at Nate's Pond were limbs missing (amelia) or foreshortened (ectromely), followed by digits missing elements (ectrodactyly), foreshortened (brachydactyly), fused (syndactyly), or duplicated (polydactyly). We also found low numbers of small eyes (micropthalmia), duplicated limbs (polymely), and curved spines (scoliosis; Table 5). Malformations were spread across three salamander and three frog species, with $A$. texanum having the highest rate $(6.2 \%)$ and $A$. opacum having the greatest number of malformation types ( 7 of 9 observed).

At Cattail Pond, we found 36 malformations among the 1,676 metamorphosing juveniles, a $2.1 \%$ malformation rate. The major malformation type at Cattail Pond was eye discoloration, which affected $L$. clamitans juveniles. Two salamander species ( $A$. opacum and $A$. texanum) had the highest rates of malformations, which generally consisted of missing or foreshortened limbs or digits, with single instances of a foreshortened digit, duplicated finger, and duplicated limb (Table 5).

\section{DISCUSSION}

The findings in this study expand upon our previous work (Lannoo et al., 2009; Kinney et al., 2010) emphasizing the potential value of mine spoil prairies as critical habitat for amphibian and reptile populations. From 1976-1982, our study site was a 30-m deep, open-pit strip mine, where we assume (although cannot prove) that no amphibian or reptile species occurred. During the present study, conducted in 2009 and 2010-almost three decades after reclamation was completed-26 species of amphibians and reptiles, represented by 15,844 amphibian and 334 reptile captures, were observed at drift fence/pitfall trap arrays, and individuals of nine additional species were observed incidentally (Table 1 ). Two of these species, $L$. areolatus and $C$. kirtlandii, are listed as endangered in Indiana; three species, $T$. carolina, $A$. blanchardi, and $O$. aestivus, are listed as special concern (Lannoo et al., 2009).

While the diversity of amphibians and reptiles observed at this site might be surprising given its industrial history (Lannoo et al., 2009), our species richness is similar to values found at other restored wetlands in the Midwest. For example, Brodman et al. (2006) reported 10 amphibian species collected at a restored prairie (Kankakee Sands) in northwestern Indiana, Timm and Meretsky (2004) documented nine frog and toad species at a reclaimed mine area in southwest Indiana (near HFWA-W), Walston and Mullin (2007) reported 10 amphibian species at a pond in Illinois, and Hocking et al. (2008) reported 15 amphibian species at ponds located within an oak-hickory forest in Missouri. Similarly, our amphibian and reptile abundance levels were comparable to those found by Palis (2007) at constructed wetlands on a conservation preserve, with juveniles accounting for the majority of captures.

Some amphibian species favored certain pond types. Species associated with ephemeral wetlands (e.g., $A$. opacum, L. sphenocephalus) were more abundant at $\mathrm{Na}$ te's Pond (Table 2), while species preferring more permanent bodies of water, such as L. clamitans (Minton, 2001), were more common at Cattail Pond (Table 3). These observations are consistent with the conclusions of Pechmann et al. (1989), who noted that pond hydroperiod is a determining factor in amphibian species diversity and community structure. These results are also consistent with Lannoo (1998), who noted that a mosaic of wetland types is likely to ensure successful amphibian breeding independent of hydroperiod. It is likely that this amphibian diversity stems in part from the presence of these various wetland types, as well as by a variety of upland habitat types, including expansive grasslands surrounded by woodlands of various sizes (Figure 1).

We demonstrate that at our study site, amphibians and reptiles are represented by high numbers of species and relatively high abundances within several species (Table 1 ). We also demonstrate that pond-breeding amphibians, such as $A$. opacum, $A$. texanum, N. viridescens, $L$. areolatus, L. clamitans, and $L$. sphenocephalus, are successfully reproducing (Tables 2 and 3), and recruiting breeding adults into their populations (Table 4 ).

Post-industrial landscapes can be contaminated with chemical products or byproducts, many of which are known to have an impact on amphibian development (Rowe et al., 1998; Hopkins et al., 2000; Lannoo, 2008). The fact that malformation rates at our wetland sites were comparable with background rates of malformations (Lannoo, 2008), suggests no obvious influence of contaminants resulting from past mining activities on the health status of current amphibian populations, although we recognize that more subtle effects, for example on immune systems (Davidson et al., 2007; but see Kinney et al., 2011), may be occurring.

The diversity and abundance of amphibians and reptiles at HFWA-W may be attributed to at least three factors: the presence of a variety of wetland and upland habitat types (Figure 1), the presence of nearby ( $3 \mathrm{~km}$; Engbrecht et al., 2013) offsite source populations with access to the site, and ecosystem management practices by IDNR biologists. At our study site, most wetlands are the result of natural slumping or depressions created during post-mining reclamation. While these basins were created incidentally, their structure provides insight into how restoration biologists can favor amphibians and reptiles when re-contouring reclaimed habitats. It is possible that the numerous railroad right-of-ways associated with coal extraction are serving as wildlife corridors. Because the ecology of HFWA-W was destroyed by mining activities 35 years ago, the colonization of amphibians and reptiles at HFWA-W must have been a relatively recent 
Table 5. Malformation rates in newly metamorphosed amphibians at Hillenbrand Fish and Wildlife Area in 2009 and 2010 sorted by wetland, species, and malformation type. Definitions of malformation types follow Meteyer (2000) and Lannoo (2008).

\begin{tabular}{|c|c|c|c|c|c|c|c|c|c|c|c|}
\hline $\begin{array}{l}\text { Nate's Pond } \\
\text { Species }\end{array}$ & 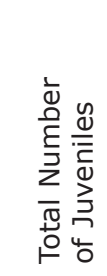 & 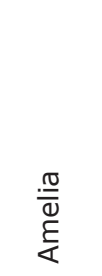 & 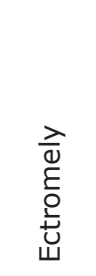 & 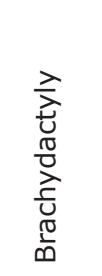 & 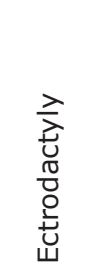 & $\begin{array}{l}\frac{\lambda}{\lambda} \\
\frac{U}{0} \\
\frac{0}{0} \\
\frac{\lambda}{0} \\
0\end{array}$ & 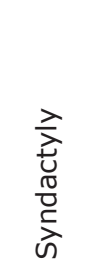 & 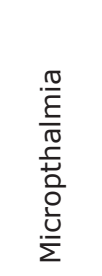 & 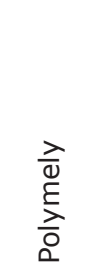 & $\begin{array}{l}\frac{n}{n} \\
\frac{.0}{0} \\
\text { v }\end{array}$ & 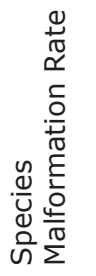 \\
\hline Ambystoma texanum & 211 & 4 & 6 & 2 & 0 & 1 & 0 & 0 & 0 & 0 & $6.2 \%$ \\
\hline Ambystoma opacum & 1,694 & 19 & 11 & $1 \overline{6}$ & 17 & 2 & 3 & 0 & 0 & 1 & $4.1 \%$ \\
\hline Pseudacris crucifer & 40 & 1 & 0 & 0 & 0 & 0 & 0 & 0 & 0 & 0 & $2.5 \%$ \\
\hline Lithobates sphenocephalus & 868 & 0 & 1 & 0 & 0 & 0 & 0 & 1 & 1 & 0 & $0.3 \%$ \\
\hline Lithobates areolatus & 2,389 & 1 & 1 & 0 & 0 & 0 & 0 & 1 & 0 & 0 & $0.1 \%$ \\
\hline Notophthalmus viridescens & 1,186 & 0 & 1 & 0 & 0 & 0 & 0 & 0 & 0 & 0 & $0.1 \%$ \\
\hline Total & 6,388 & 25 & 20 & 18 & 17 & 3 & 3 & 2 & 1 & 1 & - \\
\hline Malformations Rate by Type & - & $0.4 \%$ & $0.3 \%$ & $0.3 \%$ & $0.3 \%$ & $0.1 \%$ & $0.1 \%$ & $0.0 \%$ & $0.0 \%$ & $0.0 \%$ & - \\
\hline
\end{tabular}

Overall Malformation Rate $1.4 \%$

\begin{tabular}{|c|c|c|c|c|c|c|c|c|}
\hline $\begin{array}{l}\text { Cattail Pond } \\
\text { Species }\end{array}$ & 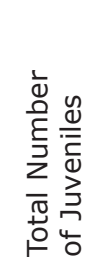 & 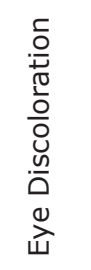 & 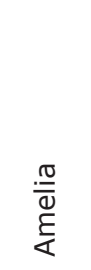 & 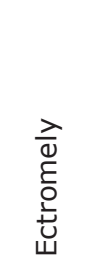 & 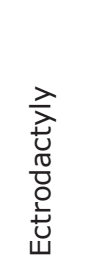 & 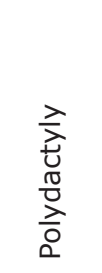 & 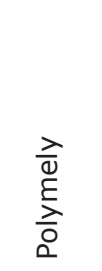 & 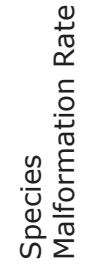 \\
\hline Ambystoma texanum & 72 & 0 & 2 & 1 & 0 & 1 & 0 & $5.6 \%$ \\
\hline Ambystoma opacum & 63 & 0 & 0 & 2 & 1 & 0 & 0 & $4.8 \%$ \\
\hline Lithobates clamitans & 1,541 & 19 & 5 & 4 & 0 & 0 & 1 & $1.9 \%$ \\
\hline Total & 1,676 & 19 & 7 & 7 & 1 & 1 & 1 & - \\
\hline Malformations Rate by Type & - & $1.1 \%$ & $0.4 \%$ & $0.4 \%$ & $0.1 \%$ & $0.1 \%$ & $0.1 \%$ & - \\
\hline
\end{tabular}

Overall Malformation Rate $2.1 \%$

event, originating from offsite populations (Lannoo et al., 2009). The habitat surrounding HFWA-W consists of a mosaic of pre-SMCRA forested mined land, livestock pasture, and agricultural fields.

Galán (1997), working in Spain, reported that during the initial years following mining, the first amphibians captured were juveniles. Similarly, we suspect juvenile dispersal was the driving force behind colonization events at HFWA-W (Lannoo et al., 2009). Newly metamorphosed individuals were captured immigrating into each wetland, and may be driving metapopulation dynamics (Sinsch, 1997; Marsh and Trenham, 2000; Semlitsch, 2000; Semlitsch, 2008).

Galán (1997) also noted that breeding was not detected until five years after reclamation, and suggested that more than 10 years are needed for amphibian and reptile communities to reach pre-disturbance diversity and abundance levels. If Galán's estimations are true, amphibian and reptile communities at HFWA-W should now be at pre-mining population levels (mining activities HFWA-W ended in 1982). In fact, amphibian and reptile diversity and abundance numbers at this site are likely higher than before mining activities, when the site was used for agriculture, and certainly higher than when the site was an open-pit mine. In southwest Indiana, pre-settlement grassland habitat occurred in scattered "pocket prairies," with more continuous prairie occurring to the west, in Illinois, and to the north across the Prairie Peninsula into northwest Indiana (Transeau, 1935; Gordon, 1936). The presence of mining and subsequent reclamation to grassland in southwestern Indiana has paradoxically resulted in a resurgence of grassland habitat in this region of the state, and it appears that the amphibians and reptiles of the region have responded in a robust way.

\section{ACKNOWLEDGEMENTS}

We thank K. Smith, R. Ronk, and B. Feaster for their support, and for access to Hillenbrand Fish and Wildlife Area. We also thank A. Robinson, T. Wheat, S. Lannoo, J. Ryan, A. Leffel, and N. Lindel for their field and technical assistance and to J. Maerz, B. Mitchell, J. Whitaker, and S. Lannoo for comments on earlier drafts. This project was supported by State Wildlife Grant (SWIG) number E2-08-WDS13 awarded by the Indiana Department of Natural Resources. All procedures were in accordance with IACUC number 3-24-2008 issued by Indiana State University, and Scientific Purposes License Permit number 09-0084 issued by the Indiana Department of Natural Resources.

\section{LITERATURE CITED}

Anderson, L. R., and J. A. Arruda. 2006. Land use and anuran biodiversity in southeast Kansas, USA. Am- 
phibian and Reptile Conservation 4:46-59.

Bajema, R. A., T. L. DeVault, P. E. Scott, and S. L. Lima. 2001. Reclaimed coal mine grasslands and their significance for Henslow's Sparrows in the American Midwest. Auk 118:422-431.

Böhm M., B. Collen, J. E. M. Baillie, P. Bowles, J. Chanson, N. Cox, G. Hammerson, M. Hoffmann, S. R. Livingstone, M. Ram, A. G. J. Rhodin, S. N. Stuart, P. P. van Dijk, B. E. Young, L. E. Afuang, A. Aghasyan, A. García, C. Aguilar, R. Ajtic, F. Akarsu, L. R. V. Alencar, A. Allison, N. Ananjeva, S. Anderson, C. Andrén, D. Ariano-Sánchez, J. Camilo Arredondo, M. Auliya, C. C. Austin, A. Avci, P. J. Baker, A. F. Barreto-Lima, C. L. Barrio-Amorós, D. Basu, M. F. Bates, A. Batistella, A. Bauer, D. Bennett, W. Böhme, D. Broadley, R. Brown, J. Burgess, A. Captain, S. Carreira, M. del Rosario Castañeda, F. Castro, Alessandro Catenazzi, J. R. Cedeño-Vázquez, D. G. Chapple, M. Cheylan, D. F. Cisneros-Heredia, D. Cogalniceanu, H. Cogger, C. Corti, G. C. Costa, P. J. Couper, T. Courtney, J. Crnobrnja-Isailovic, P-A. Crochet, B. Crother, F. Cruz, J. C. Daltry, R. J. Ranjit Daniels, I. Das, Anslem de Silva, A. C. Diesmos, L. Dirksen, T. M. Doan, C. K. Dodd Jr., J. S. Doody, M. E. Dorcas, J. D. de Barros Filho, V. T. Egan, E. H. El Mouden, D. Embert, R. E. Espinoza, A. Fallabrino, X. Feng, Z-J. Feng, L. Fitzgerald, O. Flores-Villela, F. G. R. França, D. Frost, H. Gadsden, T. Gamble, S. R. Ganesh, M. A. Garcia, J. E. García-Pérez, J. Gatus, M. Gaulke, P. Geniez, A. Georges, J. Gerlach, S. Goldberg, J-C. T. Gonzalez, D. J. Gower, T. Grant, E. Greenbaum, C. Grieco, P. Guo, A. M. Hamilton, K. Hare, S. B. Hedges, N. Heideman, C. Hilton-Taylor, R. Hitchmough, B. Hollingsworth, M. Hutchinson, I. Ineich, J. Iverson, F. M. Jaksic, R. Jenkins, U. Joger, R. Jose, Y. Kaska, U. Kaya, J. S. Keogh, G. Köhler, G. Kuchling, Y. Kumlutaş, A. Kwet, E. La Marca, W. Lamar, A. Lane, B. Lardner, C. Latta, G. Latta, M. Lau, P. Lavin, D. Lawson, M. LeBreton, E. Lehr, D. Limpus, N. Lipczynski, A. S. Lobo, M. A. López-Luna, L. Luiselli, V. Lukoschek, M. Lundberg, P. Lymberakis, R. Macey, W. E. Magnusson, D. L. Mahler, A. Malhotra, J. Mariaux, B. Maritz, O. A. V. Marques, R. Márquez, M. Martins, G. Masterson, J. A. Mateo, R. Mathew, N. Mathews, G. Mayer, J. R. McCranie, G. J. Measey, F. Mendoza-Quijano, M. Menegon, S. Métrailler, D. A. Milton, C. Montgomery, S. A. A. Morato, T. Mott, A. Muñoz-Alonso, J. Murphy, T. Q. Nguyen, G. Nilson, C. Nogueira, H. Núñez, N. Orlov, H. Ota, J. Ottenwalder, T. Papenfuss, S. Pasachnik, P. Passos, O. S. G. Pauwels, N. Pérez-Buitrago, V. Pérez-Mellado, E. R. Pianka, J. Plequezuelos, C. Pollock, P. Ponce-Campos, R. Powell, F. Pupin, G. E. Quintero Díaz, R. Radder, J. Ramer, A. R. Rasmussen, C. Raxworthy, R. Reynolds, N. Richman, E. L. Rico, E. Riservato, G. Rivas, P. L. B. da Rocha, M-O. Rödel, L. Rodríguez Schettino, W. M. Roosenburg, J. P. Ross, R. Sadek, K. Sanders, G. Santos-Barrera, H. H. Schleich, B. R. Schmidt, A. Schmitz, M. Sharifi, G. Shea, H-T. Shi, R. Shine, R. Sindaco, T. Slimani, R. Somaweera, S. Spawls, P. Stafford, R. Stuebing, S. Sweet, E. Sy, H. J. Temple, M. F. Tognelli, K. Tolley, P. J. Tolson, B. Tuniyev, S. Tuniyev, N. Üzüm, G. van Buurt, M. Van Sluys, A. Velasco, M. Vences, M. Veselý, S. Vinke, T. Vinke, G. Vogel, M. Vogrin, R. C. Vogt, O. R. Wearn, Y. L. Werner, M. J. Whiting, T. Wiewandt, J. Wilkinson, B. Wilson, S. Wren, T.
Zamin, K. Zhou, and G. Zug. 2013. The conservation status of the world's reptiles. Biological Conservation 157:372-385.

Bradford, D. F. 2005. Factors implicated in amphibian population declines in the United States. In M. J. Lannoo (ed.) Amphibian Declines: The Conservation Status of United States Species, pp. 915-925. University of California Press, Berkeley, California.

Brodman, R., M. Parrish, H. Kraus, and S. Cortwright. 2006. Amphibian biodiversity recovery in a largescale ecosystem restoration. Herpetological Conservation and Biology 1:101-108.

Carrozzino, A. L. 2009. Evaluating wildlife response to vegetation restoration on reclaimed mine lands in southwestern Virginia. M.S. Thesis, Virginia Polytechnic Institute and State University, Blacksburg, Virginia.

Chessman, B. C. 2011. Declines of freshwater turtles associated with climatic drying in Australia's Murray-Darling Basin. Wildlife Research 38:664-671.

Christy, M. T. 1996. The efficacy of using passive integrated transponder (PIT) tags without anesthetic in free-living frogs. Australian Zoologist 30:139-142.

Collins, J. P. and M. L. Crump. 2009. Extinction In Our Times: Global Amphibian Decline. Oxford University Press, New York.

Collins, J. P., and A. Storfer. 2003. Global amphibian declines: sorting the hypotheses. Diversity and Distributions 9:89-98.

Daszak, P., D. E. Scott, A. M. Kilpatrick, C. Faggioni, J. W. Gibbons, and D. Porter. 2005. Amphibian population declines at Savannah River site are linked to climate, not chytridiomycosis. Ecology 86:3232-3237.

Davidson, C., M. F. Benard, H. B. Shaffer, J. M. Parker, C. O'Leary, J. M. Conlon, and L. A. Rollins-Smith. 2007. Effects of chytrid and carbaryl exposure on survival, growth and skin peptide defense in Foothill Yellow-legged Frogs. Environmental Science and Technology 41:1771-1776.

DeVault, T. L., P. E. Scott, R. A. Bajema, and S. L. Lima. 2002. Breeding bird communities of reclaimed coal mine grasslands in the American Midwest. Journal of Field Ornithology 7:268-275.

Dodd, C. K., Jr., and D. E. Scott. 1994. Drift fences encircling breeding sites. In W. R. Heyer, M. A. Donnelly, R. W. McDiarmid, L-A. C. Hayek, and M. S. Foster (eds.), Measuring and Monitoring Biological Diversity. Standard Methods for Amphibians, pp. 125-130. Smithsonian Institution Press, Washington, D.C.

Engbrecht, N. J., P. J. Williams, J. R. Robb, D. R. Karns, M. J. Lodato, T. Gerardot, and M. J. Lannoo. 2013. Is there hope for the Hoosier Frog? An update on the status of Crawfish Frogs (Lithobates areolatus) in Indiana, with recommendations for their conservation. Proceedings of the Indiana Academy of Science 121:147-157.

Galán, P. 1997. Colonization of spoil benches of an opencast lignite mine in Northwest Spain by amphibians and reptiles. Biological Conservation 79:187-195.

Gallant, A. L., R. W. Klaver, G. S. Casper, and M. J. Lannoo. 2007. Global rates of habitat loss and implications for amphibian conservation. Copeia 2007:967979.

Gibbons, J. W., and D. H. Bennett. 1974. Determination of anuran terrestrial activity patterns by a drift fence method. Copeia 1974:237-243.

Gibbons, J. W., D. E. Scott, T. J. Ryan, K. A. Buhlmann, 
T. D. Tuberville, B. S. Metts, J. L. Greene, T. Mills, Y. Leiden, and C. T. Winne. 2000. The global decline of reptiles, déjà vu amphibians. BioScience 50:653666.

Gibbons, J. W., and R. D. Semlitsch. 1981. Terrestrial drift fences with pitfall traps: An effective technique for quantitative sampling of animal populations. Brimleyana 7:1-16.

Gordon, R. B. 1936. A preliminary vegetation map of Indiana. American Midland Naturalist 17:866-877.

Heemeyer, J. L., V. C. Kinney, N. J. Engbrecht, and M. J. Lannoo. 2010. The biology of Crawfish Frogs (Lithobates areolatus) prevents the full use of telemetry and drift fence techniques. Herpetological Review 41:42-45.

Hersikorn, B. D., J. J. C. Cibrowski, and J. E. G. Smits. 2010. The effects of oil sands wetlands on Wood Frogs (Rana sylvatica). Toxicological \& Environmental Chemistry 92:1513-1527.

Hersikorn, B. D., and J. E. G. Smits. 2011. Compromised metamorphosis and thyroid horomone changes in Wood Frogs (Lithobates sylvaticus) raised on reclaimed wetlands on the Athabasca oil sands. Environmental Pollution 159:596-601.

Hingtgen, T. M., and W. R. Clark. 1984. Small mammal recolonization of reclaimed coal surface-mined land in Wyoming. Journal of Wildlife Management 48:1255-1261.

Hocking, D. J., T. A. Rittenhouse, B. B. Rothermel, J. R. Johnson, C. A. Conner, E. B. Harper, and R. D. Semlitsch. 2008. Breeding and recruitment phenology of amphibians in Missouri Oak-Hickory Forests. American Midland Naturalist 160:41-60.

Hopkins, W. A., J. Congdon, and J. K. Ray. 2000. Incidence and impact of axial malformations in larval Bullfrogs (Rana catesbeiana) developing in sites polluted by a coal-burning power plant. Environmental Toxicology and Chemistry 19:862-868.

Jones, S. R., and R. C. Cushman. 2004. The North American Prairie; Peterson Field Guide Series; Houghton Mifflin, New York, New York.

Kinney, V. C. 2011. Adult survivorship and juvenile recruitment in populations of Crawfish Frogs (Lithobates areolatus), with additional consideration of the population sizes of associated pond breeding species. M.S. Thesis, Indiana State University, Terre Haute, Indiana.

Kinney, V. C., N. J. Engbrecht, J. L. Heemeyer, and M. J. Lannoo. 2010. New records for amphibians and reptiles in southwest Indiana. Herpetological Review $41: 387$.

Kinney, V. C., J. L. Heemeyer, A. P. Pessier, and M. J. Lannoo. 2011. Seasonal pattern of Batrachochytrium dendrobatidis infection and mortality in Lithobates areolatus: Affirmation of Vredenburg's "10,000 zoospore rule." PLoS ONE 6(3): e16708. doi:10.1371/ journal.pone.0016708.

Lamoureux, V. S., J. C. Maerz, and D. M. Madison. 2002. Premigratory autumn foraging forays in the Green Frog, Rana clamitans. Journal of Herpetology $36: 245-254$.

Lannoo, M. J. 1998. Amphibian conservation and wetland management in the upper Midwest: A catch-22 for the Cricket Frog? In M. J. Lannoo (ed.) Status and Conservation of Midwestern Amphibians, pp. 330-339. University of Iowa Press, Iowa City, Iowa.

Lannoo, M. J. 2008. Malformed Frogs: The Collapse of
Aquatic Ecosystems. University of California Press, Berkeley, California.

Lannoo, M. J., V. C. Kinney, J. L. Heemeyer, N. J. Engbrecht, A. L. Gallant, and R. W. Klaver. 2009. Mine spoil prairies expand critical habitat for endangered and threatened amphibian and reptile species. Diversity $1: 118-132$

Lannoo, M. J., K. Lang, T. Waltz, and G. S. Phillips. 1994. An altered amphibian assemblage: Dickinson County, Iowa, 70 years after Frank Blanchard's survey. American Midland Naturalist 131:311-319.

Loughman, Z. J. 2005. Natural history and conservation biology of a southern West Virginia contour surface mine reptile and amphibian community. M.S. Thesis, Marshall University, Huntington, West Virginia.

Marsh, D. M., and P. C. Trenham. 2000. Metapopulation dynamics and amphibian conservation. Conservation Biology 15:40-49.

Meteyer, C. A. 2000. Field Guide to Malformations of Frogs and Toads. U.S. Geological Survey Biological Science Report USGS/BRD/BSR-2000-0005 at http://www.nwhc.usgs.gov/publications/factsheets/pdfs/frog.pdf.

Minton, S. A., Jr. 2001. Amphibians and Reptiles of Indiana. Second Edition. Indiana Academy of Science, Indianapolis, Indiana.

Myers, C. W., and W. D. Klimstra. 1963. Amphibians and reptiles of an ecologically disturbed (strip-mined) area in southern Illinois. American Midland Naturalist $70: 126-132$.

Nikiforuk, A. 2010. Tar Sands: Dirty Oil and the Future of a Continent. Greystone Books, Vancouver, Canada. $272 \mathrm{pp}$.

Office of Surface Mining Reclamation and Control. 2008. Surface Mining Control and Reclamation Act of 1977 (Public Law 95-87). U.S. Department of Interior, Washington, D.C., USA. Available at: http://www. osmre.gov/topic/SMCRA/SMCRA.shtm.

Palis, J. G. 2007. If you build it, they will come: herpetofaunal colonization of constructed wetlands and adjacent terrestrial habitat in the Cache River drainage of southern Illinois. Transactions of the Illinois State Academy of Science 100:177-189.

Pechmann, J. H. K., D. E. Scott, J. W. Gibbons, and R. D. Semlitsch. 1989. Influence of wetland hydroperiod on diversity and abundance of metamorphosing juvenile amphibians. Wetland Ecology and Management $1: 3-11$.

Pollet, I., and L. I. Bendell-Young. 2000. Amphibians as indicators of wetland quality in wetlands formed from oils sands effluent. Environmental Toxicology and Chemistry 19:2589-2597.

Reading, C. J., L. M. Luiselli, G. C. Akani, X. Bonnet, G. Amori, J. M. Ballouard, E. Filippi, G. Naulleau, D. Pearson, and L. Rugiero. 2010. Are snake populations in widespread decline? Biological Letters doi:10.1098/rsbi2010.0373.

Reece, E. and J. J. Krupa. 2013. The Embattled Wilderness: The Natural and Human History of Robinson Forest and the Fight for its Future. University of Georgia Press, Athens. 144 pp.

Rowe, C. L., O. M. Kinney, and J. D. Congdon. 1998. Oral deformities in tadpoles of the Bullfrog (Rana catesbeiana) caused by conditions in polluted habitats. Copeia 1998:244-246.

Scott, P. E., T. L. DeVault, R. A. Bajema, and S. L. Lima. 2002. Grassland vegetation and bird abundances on 
reclaimed midwestern coal mines. Wildlife Society Bulletin 30:1006-1014.

Scott, P. E., and S. L. Lima. 2004. Exotic grasslands on reclaimed midwestern coal mines: an ornithological perspective. Weed Technology 18:1518-1521.

Semlitsch, R. D. 2000. Principles for management of aquatic-breeding amphibians. Journal of Wildlife Management 64:615-631.

Semlitsch, R. D. 2008. Differentiation migration and dispersal processes for pond-breeding amphibians. Journal of Wildlife Management 72:260-267.

Sinervo, B., F. Méndez-de-la-Cruz, D. B. Miles, B. Heulin, E. Bastiaans, M. Villagrán-Santa Cruz, R. Lara-Resendiz, N. Martinez-Méndez, M. Lucia Calderón-Espinoza, R. Nelsi Meza-Lázaro, H. Gadsden, L. Javier Avila, M. Morando, I. J. De la Riva, P. Victoriano Sepulveda, C. Frederico Duarte Rocha, N. Ibargüengoytia, C. Aguilar Puntriano, M. Massot, V. Lepetz, T. A. Oksanen, D. G. Chapple, A. M. Bauer, W. R. Branch, J. Colbert, J. W. Sites Jr. 2010. Erosion of lizard diversity by climate change and altered thermal niches. Science 328:894-899.
Sinsch, U. 1997. Postmetamorphic dispersal and recruitment of first breeders in a Bufo calamita metapopulation. Oecologia 112:42-47.

Stone, E. R. 2007. Measuring impacts of restoration on small mammals in a mixed-grass Colorado prairie. Ecological Restoration 25:183-190.

Stuart, S. N, J. S. Chanson, N. A. Cox, B. E. Young, A. S. L. Rodrigues, D. L. Fischman, and R. W. Waller. 2004. Status and trends of amphibian declines and extinctions worldwide. Science 306:1783-1786.

Timm, A., and V. Meretsky. 2004. Anuran habitat use on abandoned and reclaimed mining areas of southwestern Indiana. Proceedings of the Indiana Academy of Science 113:140-146.

Transeau, E. N. 1935. The prairie peninsula. Ecology $16: 423-437$.

Wake, D. B. 2012. Facing extinction in real time. Science 335:1052-1053.

Walston, L. J., and S. J. Mullin. 2007. Responses of a pond-breeding amphibian community to the experimental removal of predatory fish. American Midland Naturalist 157:63-73. 